\title{
Penguatan Ekonomi Masyarakat Desa Kubang Kecamatan Sukamulya Kabupaten Tangerang Melalui Industri Jamu Banteng Gde
}

\author{
Gunartin,Diah Wulan Sari \\ Dosen Fakultas Keguruan Dan Ilmu Pendidikan Universitas Pamulang \\ Email : dosen01339@unpam.ac.id
}

\begin{abstract}
ABSTRAK
Tujuan dari penelitian yang mengambil obyek industri jamu Banteng Gde di Desa Kubang Kecamatan Sukamulya Kabupaten Tangerang ini untuk menggali informasi dan mendeskripsikan tentang kontribusi industri jamu dalam perannya sebagai penguatan ekonomi masyarakat di sekitar lokasi berdirinya industri jamu Banteng Gde.

Peneliti menggunakan metode kualitatif deskriptif mencapai tujuan penelitian, dengan peneliti sebagai intrumennya. Data dikumpulkan melalui observasi, wawancara dan dukungan dokumentasi dengan pengesahan data secara triangulasi sumber dan metode. Data penelitian bersifat primer dikumpulkan dengan cara observasi dan wawancara langsung terhadap informan. Dalam penelitian ini penentuan sample sebagai informan berdasarkan kearurasian informasi yang dibutuhkan yaitu ppemilik, karyawan, konsumen dan masyarakat sekitar. teknik pengumupulan data melalui obserwasi, dokumentasi dan wawancara mendalam guna memperoleh data yang akurat, serta dianalisa secara keseluruhan atau menjelaskan tahap akhir untuk dideskripsikan, sehingga disebut teknik analisis deskriptif.

Hasil penelitian dapat dideskripsikan bahwa penguatan ekonomi masyarakat Desa Kubang Kecamatan Sukamulya Kabupaten Tangerang melalui industri jamu dapat ditunjukkan dengan menggeliatkan kegiatan ekonomi di sekitar lokasi industri jamu dengan dibukanya warung makan, warung kopi, rumah kontrakan serta toko klontong. Kontribusi industri jamu yang tampak nyata yaitu sebagian masyarakat menjadi karyawan industri jamu Banteng Gde yang merubah pendapatan mereka.
\end{abstract}

Kata kunci: Penguatan Ekonomi Masyarakat, Industri Jamu 


\section{PENDAHULUAN}

\section{A. Konteks Penelitian}

Tingkat industri yang dihasilkan oleh negara merupakan salah satu faktor yang mempengaruhi tumbuh kembangnya perekonomian di negara tersebut. Meningkatnya hasil industri yang dihasilkan menunjukkan volume faktor produksi yang digunakan dalam proses industri. Peningkatan volume hasil industri tidak selalu didominasi oleh industri-industri besar, industri kecil yang termasuk dalam katagori Usaha Mikro Kecil dan Menengah (UMKM) juga mempunyai andil yang besar dalam berkontribusi menggeliatkan perokonomian. Dengan demikian UMKM mempunyai peran yang sangat besar dalam pertumbuhan ekonomi di Indonesia. Rudjito (2003) menyatakan bahwa perekonomian di Indonesia dikuatkan oleh peran pentingnya Usaha Kecil dan Menengah (UKM) dari sudut pandang jumlah usaha atau penyediaan lapangan kerja.

Karakteristik umum UMKM antara lain: manajemen mandiri, modal sendiri, daerah pemasaran pada tingkat skala lokal, aset perusahaan relatif kecil, dan jumlah karyawan terbatas. Meskipun masih dalam katagori relatif kecil UMKM memiliki asas kebersamaan, kemandirian, keseimbangan kemajuan, berkelanjutan, efesiensi keadilan, ekonomi yang demokratis, serta kesatuan ekonomi nasional dalam menyelenggarakan UMKM. Di Indonesia, UMKM tumbuh dengan pesat, sebagaimana perannya UMKM merupakan bagian dari penguatan ekonomi. Pentingnya peran UMKM serta strateginya bertahan pada kondisi krisis ekonomi mencerminkan kontribusinya terhadap tumbuh kembangnya perekonomian, penyediaan lapangan kerja serta perannya pada pendistribusian hasil industri.

UMKM untuk tahun 2016 berkontribusi pada Produk Domestik Bruto (PDB) sebesar $57 \%-60 \%$ dengan tingkat penyerapan tenaga kerja sekitar 97\% dari total tenaga kerja tingkat nasional (Profil Bisnis UMKM oleh LPPI dan BI tahun 2016). UMKM di Indonesia merata di semua wilayah termasuk di daerah Kabupaten Tangerang khususnya di Kecamatan Sukamulya dan Balaraja yang terletak di Tangerang Barat merupakan salah satu kecamatan dengan kawasan indusrti dengan skala kecil maupun besar diantaranya industri tekstil, industri elektronik, industri sepatu dan industri jamu. Dengan demikian ketersediaan lapangan pekerjaan lebih banyak dan bisa dimanfaatkan masyarakat sekitar sebagai mata pencaharian utama dalam memenuhi kebutuhan hidupnya. Berdasarkan uraian di atas, sektor industri masih mendominasi peranan penting terhadap tumbuh kembangnya dan penguatan ekonomi Kabupaten Tangerang.

Di Kabupaten Tangerang khususnya daerah Sukamulya terdapat beberapa industri seperti industri tekstil, alat-alat kendaraan sampai berbagai jenis industri 
makanan. Desa Kubang merupakan daerah bagian dari Kecamatan Sukamulya dimana merupakan daerah pabrikasi, artinya banyak industri skala kecil, menengah dan besar yang menjalankan usahanya di daerah tersebut. Di Desa Kubang berdiri salah satu indutri jamu Banteng Gde yang sangat membantu masyarakat dalam meningkatkan pendapatan perkapita daerah. Jamu merupakan salah satu warisan kebudayaan nenek moyang bangsa Indonesia, yang menggambarkan keragaman budaya, kekayaan alam, keahlian dalam meracik, serta kepedulian rakyat Indonesia terhadap kesehatan.

Industri jamu Banteng Gde yang beralamatkan di Desa Kubang Kecamatan Sukamulya Kabupaten Tangerang berdiri tahun 2014. Didirikan berdasarkan kepiawaian pemilik industri jamu dalam membaca peluang pasar dengan baik sehingga muncul ide untuk mendirikan industri jamu Banteng Gde. Industri ini didirikan ditengah masyarakat yang gemar minum jamu.amat menyukai jamu. Sebelum ada industri jamu dan banyaknya permintaan jamu di masyarakat tersebut, pedagang jamu tradisional mematok harga jamu dengan harga lebih tinggi. Hal inilah yang mendorong pemilik jamu untuk mendirikan industri jamu untuk memenuhi permintaan masyarakat baik kualitas maupun harganya relatif murah, dan diberi nama Industri Jamu Banteng Gde. Bahkan industri jamu tersebut banyak mempekerjakan masyarakat sekitar untuk menjadi tenaga kerja dipabriknya. Masyarakat yang awalnya berpenghasilan dari sektor pertanian, kini sebagian masyarakat sekitar industri jamu alih profesi dengan menjadi karyawan pabrik serta berpenghasilan sesuai upah minimum regional (UMR) sekitar Rp3.000.000/bulan sangat terbantu dalam memenuhi kebutuhan hidup warga sekitar. Dampak positif lainnya, membuka peluang usaha baru bagi warga sekitar dengan membuka warung atau toko yang menawarkan kebutuhan pokok dapat berupa warung makan serta sewa tempat tinggal bagi karyawan yang berasal dari luar daerah.

Pendirian industri jamu ini juga menggerakan perekonomian dari sektor pertanian toga sebagai bahan dasar pembuatan jamu. Selain menyediakan lapangan pekerjaan tentu tidak kalah pentingnya yaitu meningkatnya pemanfaatan sumber daya ekonomi yang berdampak pada peningkatan pendapatan asli daerah maupun peningkatan kesejahteraan masyarakat setempat. Berdasarkan konteks penelitian diatas maka peneliti tertarik mengadakan penelitian mengenai Penguatan Ekonomi Masyarakat Melalui Industri Jamu Banteng Gde di Desa Kubang Kecamatan Sukamulya Tangerang Banten.

\section{B. Fokus Penelitian}

Industri jamu Banteng Gde merupakan kegiatan industri yang sudah berlangsung kurang lebih 4 tahun, waktu yang dapat dibilang relatif singkat untuk menjalankan usaha, tetapi sudah mampu 
menunjukkan kontribusinya dalam menggerakkan perekonomian masyarakat Desa Kubang Sukamulya dengan memperkerjakan masyarakat sekitar. Keberadaan industri jamu Banteng Gde sangat membentu pemerintah daerah setempat dalam pendapatan daerah. Berdasarkan kondisi tersebut penelitian ini difokuskan pada penggalian informasi bagaimana melalui Industri Jamu Banteng Gde mampu sebagai penguatan ekonomi masyarakat Desa Kubang Kecamatan Suka Mulya Kabupaten Tangerang.

\section{Tujuan Penelitian}

Mengacu pada rokus
penelitian, tujuan dari
dilaksanakannya penelitian yaitu
untuk
mendeskripsikan/menggambarkan
kiprahnya Industri Jamu Banteng
Gde sehingga mampu
berkontribusi sebagai penguatan
ekonomi masyarakat Desa Kubang
Kecamatan Sukamulya Kabupaten
Tangerang.

\section{KAJIAN TEORI}

\section{A. Ekonomi Masyarakat}

Penguatan ekonomi masyarakat merupakan proses untuk memperbaiki kualitas masyarakat disektor ekonomi. Sedang menurut Sanusi (2011) menyebutkan bahwa penguatan ekonomi merupakan proses yang menyebabkan pendapatan per kapita penduduk suatu negara meningkat dalam jangka panjang. Terdapat hal penting dalam makna definisi membengun ekonomi tersebut di atas, yaitu: (1) suatu proses yang berarti merupakan perubahan yang terjadi terus menerus, (2) suatu usaha untuk menaikkan tingkat pendapatan per kapita, (3) kenaikan pendapatan per kapita itu harus terus berlangsung dalam jangka panjang.

Penguatan ekonomi masyarakat menurut Sukirno (2004) merupakan pertumbuhan ekonomi yang diikuti perubahan dalam aspek lain dalam perekonomian, seperti perkembangan pendidikan, perkembangan kualifikasi SDM, perbaikan teknologi dan meningkatnya taraf kemakmuran masyarakat. Dimana tingkat kemakmuran ini umumnya diukur dari tingkat pendapatan per kapita nominal yang dihitung dengan pendekatan formula PDB dibagi dengan jumlah penduduk.

Penguatan

ekonomi masyarakat harus secara terus menerus diikuti oleh pengembangan institusi yang dapat memberi dorongan kepada pengembangan berbagai kegiatan ekonomi. Maka dari itu, dapat disimpulkan bahwa pengembangan ekonomi masyarakat merupakan proses perbaikan yang diikuti pertumbuhan ekonomi guna meningkatkan taraf kemakmuran masyarakat. Dengan demikian arah penguatan ekonomi haruslah merupakan penjabaran dari demokrasi ekonomi yang dimaknakan untuk membebaskan rakyat dari keterbelakangan dan kemiskinan seperti yang dikaji dalam pasal 33 UUD 1945. 


\section{B. Industri Jamu}

Industri adalah bidang yang menggunakan keterampilan, dan ketekunan kerja (bahasa Inggris: industrious) dan penggunaan alatalat di bidang pengolahan hasilhasil bumi, dan distribusinya sebagai dasarnya. Maka industri umumnya dikenal sebagai mata rantai selanjutnya dari usaha-usaha mencukupi kebutuhan (ekonomi) yang berhubungan dengan bumi, yaitu sesudah pertanian, perkebunan, dan pertambangan yang berhubungan erat dengan tanah.. Bidang industri dibedakan menjadi dua, yaitu industri barang dan industri jasa. Industri menurut Hardjanto dalam Hera (2005:19) adalah tiap usaha yang merupakan unit produksi yang membuat barang dan atau yang mengerjakan suatu barang atau bahan untuk masyarakat di suatu tempat tertentu.

Menurut Dumairy Dalam Rowland (2012:474) Industri dapat pula merujuk ke suatu sektor ekonomi yang di dalamnya terdapat kegiatan produktif yang mangolah barang jadi atau barang setengah jadi. Kegiatan pengolahan tersebut dapat bersifat masinal, elektrikal atau manual. Kata lain sektor industri untuk arti yang kedua ini maksudnya adalah sektor industri pengolahan (manufacturing) yakni sebagai salah satu sektor produksi atau lapangan usaha dalam perhitungan pendapatan nasional menurut pendekatan produksi.

Menurut Rowland (2012:472) Sektor industri diyakini sebagai sektor yang dapat memimpin sektor-sektor lain dalam sebuah perekonomian menuju kemajuan. Produk produk industrialisasi selalu memiliki "dasar tukar" (terms of trade) yang tinggi atau lebih menguntungkan serta meciptakan nilai tambah yang lebih besar dibandingkan produk - produk sektor lain. Hal ini disebabkan karena sektor industri memiliki produk yang sangat beragam dan mampu memberikan manfaat marjinal yang tinggi kepada pemakainya serta memberikan keuntungan yang lebih menarik. Oleh sebab itu industrialisasi dianggap sebagai "obat mujarab" untuk mengatasi masalah pembangunan ekonomi di negara berkembang.

Sektor industri merupakan komponen utama dalam pembangunan ekonomi nasional. Sektor ini tidak saja berpotensi mampu memberikan kontribusi ekonomi yang besar melalui nilai tambah, lapangan kerja dan devisa, tetapi juga mampu memberikan kontribusi yang besar dalam transformasi kultural bangsa ke arah modernisasi kehidupan masyarakat yang menunjang pembentukan daya saing nasional. Selama dua dasawarsa sebelum krisis ekonomi, peran sektor industri terhadap perekonomian nasional hampir mencapai $25 \%$. Maka dapat disimpulkan industri adalah suatu usaha atau kegiatan pengolahan bahan mentah atau barang setengah jadi menjadi barang jadi yang memiliki nilai tambah untuk mendapatkan keutungan.

Dengan semakin maraknya pendirian industri jamu, 
pemerintah wajib melindungi konsumen dengan mengeluarkan Peraturan Menteri Kesehatan No. 246/MENKES/PER/V/1990 tentang Izin Usaha Industri Obat Tradisional dan Pendaftaran Obat Tradisonal. Guna menjamin peningkatan penggunaan dan pengawasan terhadap obat tradisional, pemerintah mengeluarkan Keputusan Menteri Kesehatan No.584/ MENKES/SK/VI/1995 tentang Sentra Pengembangan dan Penerapan Pengobatan Tradisional (SP3T).

Dalam jurnal jamu indonesia, jamu adalah istilah dalam bahasa indonesia untuk obat herbal yang terbuat dari tumbuhan obat segar atau kering. Menurut Ervina (2013:1) jamu adalah obat tradisional berbahan alami warisan budaya yang telah diwariskan secara turun temurun dari generasi ke generasi untuk kesehatan. Dapat disimpulkan bahwa jamu adalah ramuan/obat alami yang terbuat dari tanaman herbal yang dipercaya masyarakat indonesia berguna untuk kesehatan dan telah diwariskan secara dari generasi ke generasi.

\section{METODOLOGI PENELITIAN}

Penelitian ini menggunakan metode kualitatif, dimaksudkan untuk menggali lebih dalam apa yang menjadi fokus penelitian, dengan cara mendeskripsikan dalam bentuk katakata dan bahasa, pada suatu konteks khusus yang alamiah dengan memanfaatkan berbagai metode alamiah melalui pengumpulan data (Moleong, 2011). Banyaknya populasi atau sampling bukan hal terpenting pada penelitian ini, melainkan lebih mengutamakan kualitas data bukan kuantitas datanya (Kriyantono, 2009). Pada penelitian ini dilakukan surve atas kegiatan/peristiwa terkait fokus penelitian yaitu menggali informasi tentang Pengutan Ekonomi Masyarakat Melalui Industri Jamu Banteng Gde di Desa Kubang Kecamatan Sukamulya Tangerang Banten.

Kehadiran peneliti selain sebagai observer, juga sebagai partisipan penuh. Artinya, selama proses penelitian, peneliti sebagai partisipan terlibat langsung dalam aktivitas pengumpulan data sampai menjadi kesimpulan akhir. Manfaat dari kehadiran peneliti sebagai partisipan penuh yaitu pengumpulan data dapat dilakukan secara efektif dan efisien, sekaligus informasi diperoleh secara langsung dari sikap dan cara informan menyampaikan informasi/pendapatnya sebagai sarana pengumpulan data.

Industri jamu Banteng Gde di Desa Kubang Kecamatan Sukamulya Kabupaten Tangerang Provinsi Banten merupakan subyek penelitian sekaligus lokasi penelitian. Hasil survei awal di Desa Kubang terdapat industri jamu yang melakukan berbagai pemberdayaan masyarakat untuk penguatan ekonomi masyarakat setempat. Sumber data yang digunakan adalah sumber data primer yang diperoleh secara langsung dari responden dengan melakukan wawancara langsung dengan pemilik industri jamu, karyawan industri jamu dan masyarakat yang berada disekitar industri jamu yang dikumpulkan sendiri oleh peneliti. Informan dipilih 
dari masyarakat yang berusia 18 tahun ke atas dengan pertimbangan dapat membeikan informasi yang akurat yang dibutuhkan oleh peneliti. Penelitian ini dalam menentukan informannya menggunakan teknik sampling purposive, agar data yang diperolehBsesuai dengan kebutuhan dan tujuan penelitian. Pernyataan Sugiyono (2010) purposive sampling yaitu teknik menentukan sampel penelitian dengan pertimbangan tertentu tujuannya agar data yang diperoleh lebih representatif. Sedangkan menurut Notoadmodjo (2010) purposive sampling merupakan teknik pengambilan sampel berdasarkan atas suatu pertimbangan tertentu seperti sifat-sifat populasi ataupun ciri-ciri yang sudah diketahui sebelumnya. Menurut Lofland dalam Istiqomah (2017) mengatakan sumber data utama dalam penelitian kualitatif berupa kata-kata dan tindakan, selebihnya merupakan data tambahan seperti dokumen. Keabsahan data dilakukan dengan triangulasi metode yang merupakan pengecekan data dari berbagai sumber dan membandingkan informasi yang diperoleh dari hasil wawancara dengan pemilik, karyawan, pelanggan dan masyarakat sekitar untuk mendapatkan informasi yang valid. Selain menggunakan triangulasi

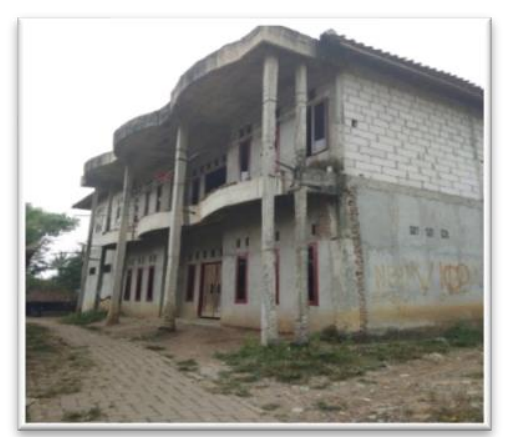

metode juga dilakukan triangulasi sumber untuk menggali kebenaran informasi dari informan. Triangulasi merupakan pengujian kredibilitas dari berbagai sumber dengan berbagai metode, sumber dan waktu (Moleong, 2014).

\section{HASIL PENELITIAN}

Awal mula didirikan pada tahun 1996 di Jawa Tengah oleh Pak Jumani beserta istrinya. Dengan modal awal yang sangat minim belia memulai usaha sebagai pedagang jamu keliling. Usaha keluarga ini terus berjalan tetapi belum dapat dikatakan berkembang. Setelah tahun 2014 keluarga pak Jumani pindah ke Desa Kubang Sukamulya dan merintis usaha jamu lagi, pelan tapi pasti industri jamu tersebut mulai nambak perkembangannya. Dari waktu ke waktu terus berkembang sampai mempunyai karyawan untuk membantu mengembangkan usahanya. Hingga tahun 2018 industri jamu pak Jumani telah memiliki 8 karyawan.

Bangunan pabrik didirikan di atas tanah seluas $600 \mathrm{M}^{2}$ yang dibeli pada tahun 2014 dan dibangun gedung industri jamu Banteng Gde dengan luas bangunan $12 \mathrm{M}^{2} \mathrm{x} 10 \mathrm{M}^{2}$.

Berikut adalah bangunan industri jamu Banteng Gde hasil dokumentasi dan observasi.

\section{Gambar bangunan industri jamu Banteng Gde (Sumber: dokumentasi peneliti 2018}

Di dalam bangunan di atas tanah seluas $120 \mathrm{~m} 2$ tersebut, pak Jumani mengembangkan usahanya dan melakukan pemberdayaan masyarakat sekitar untuk penguatan 
ekonomi masyarakat setempat. Memang untuk melakukan perekrutan besar-besaran belum bisa karena keterbatasan modal, tetapi dengan adanya aktivitas industri jamu Banteng Gde di Desa Kubang, masyarakat setempet secara tidak langsung terangkat ekonominya. Ada yang membuka warung nasi, membuka jasa penginapan atau kostkostan. Yang lebih kelihatan adanya perubahan profesi, seperti awalnya sebagai petani pekerja musiman, artinya ada bekerja kalau ada garapan tani, tetapi dengan adanya industri jamu Banteng Gde mereka bisa kulaan jamu untuk mereka jual kembali.

Jamu merupakan jenis minuman kesehatan dari bahan rempah yang diracik sedemikian rupa, peninggalah leluhur yang perlu dilestarikan karena tidak mengandung bahan kimia seperti minumamminuman yang banyak beredar di pasaran. Menurut Ernie (2013) jamu merupakan minuman tradisional berbahan baku alami warisan kebudayaan secara turun temurun dari generasi ke generasi untuk kesehatan. Sehingga dapat disimpulkan bahwa jamu merupakan ramuan/obat alami yang terbuat dari tanaman herbal yang dipercaya masyarakat Indonesia berguna untuk kesehatan dan telah diwariskan secara turun temurun dari generasi ke generasi. Teknologi yang semakin berkembang memudahkan masyarakat dalam proses pembuatan jamu tradisional, hal ini juga dirasakan oleh industri jamu Banten Gde di desa Kubang Kecamatan Sukamulya Kabupaten Tangerang Banten. Seperti halnya proses produksi jamumilik pak Jumani melalui beberapa proses tahapan sebelum dipasarkan ke konsumen.

Jamu Banteng Gde diracik dari bahan alami yang meliputi: air, gula pasir, lada hitam, cabe jawa, kayu secang, kayu manis, kayu pule, kayu sintok, kayu angin, bolong-bolong, kumis kucing, kayu rapel, kapolaga, ujung sambiloto, anyang-anyang, bidara laut, kembang cangkok, buah cangkok, jinten hitam, jinten jamu, sido wayah, siklamat, dan menthol.

Alat yang digunakan dalam proses produksi jamu Banteng Gde di Desa Kubang masih tradisional dan sederhana karena keterbatasan modal. Langkah pembuatannya jamu Banteng Gde:

1. Semua bahan membuat jamu disiapkan.

2. Bahan yang telah disiapkan, dibersihkan dan ditakar sesuai ukuran.

3. Bahan yang telah ditakar kemudian ditumbuk kasar.

4. Setelah ditumbuk kasar semua bahan dimasukan pada tempat yang berisi air mendidih. Kemudian rebus semua bahan hingga matang.

5. Setelah proses perebusan, air hasil rebusan disaring dan ditampung dalam drum plastik.

6. Setelah dingin kemudian jamu dimasukan ke dalam botol kemasan.

7. Penutupan botol kemasan jamu dilakukan dengan bantuan alat pres

8. Jamu mengalami proses sterilisasi dengan medan $\mathrm{CO} 2$ yang berfungsi untuk membunuh bakteri yang mungkin terdapat pada cairan hasil rebusan dan botol kemasan.

9. Jamu siap dipasarkan/ didistribusikan 
Proses pendistribusian produk jamu baru sebatas wilayah Tangerang, karena keterbatasan sarana dan prasarana yang dimiliki. Daerah Tangerang dijadikan pusat pemasarannya karena masyarakat Tangerang masih banyak yang mengkonsumsi jamu. Dan ini merupakan pasar potensial hasil produksi industri jamu untuk terus dikembangkan di Desa Kubang. Apalagi sebagian masyarakat masih banyak yang bekerja sebagai pekerja otot sehingga masih banyak yang percaya akan khasiat tanaman herbal atau pun yang telah diproses menjadi produk jamu.

Sistem penggajian karyawan industri jamu Banteng Gde diterapkan sistem bagi hasil yaitu dengan menghitung unit yang dihasilakn oleh karyawan. Setiap satu botol jamu terjual maka karyawan menerima keuntungan sebesar Rp.500. sedangan untuk karyawan yang mencuci botol diberikan imbalan Rp.30/botol.

Kepuasan konsumen menjadi perhatian utama pemilik dan karyawan dalam menjalankan sebuah usaha industri jamu ini. Salah satu indikator untuk mengetahui kepuasan konsumen dengan ikut terjun langsung ke lapangan, surve ke tokotoko yang menjual produk jamu Banteng Gde dengan pertimbangan lebih efektif menangani keluhan para konsumen jamu. Berdasarkan hasil wawancara dan dokumentasi dapat disimpulkan bahwa konsumen jamu Banteng Gde sebagian besar merasa puas dengan kualitas dan khasiat jamu.

Penguatan ekonomi yang telah ditimbulkan dari berdirinya industri jamu Banteng Gde dapat diukur dari mata pencaharian masyarakat sesudah berdirinya industri jamu dan tingkat pendapatan yang diterima masyarakat. Aktifitas agar memperoleh taraf hidup yang layak dan berbeda di setiap daerah sesuai dengan taraf kemampuan penduduk dan keadaan demografinya merupakan definisi mata pencaharian menurut Daldjoeni dalam Eriska (2014). Mata pencaharian masyarakat Desa Kubang yang tinggal disekitar industri jamu mengalami perubahan. Termasuk perubahan pendapatan dimana masyarakat menemukan peluang usaha setelah berdirinya industri jamu tersebut.

Pendapat Sulistiyono (2015) menyatakan bahwa terbukanya lapangan pekerjaan menyebabkan meningkatnya pendapatan masyarakat sehingga dapat memajukan taraf hidup masyarakat Berdirinya industri jamu pendapatan masyarakat mengalami perubahan karena ada berbagai jenis peluang usaha yang terbuka seperti menjadi karyawan industri jamu, buruh cuci botol jamu, membuka kontrakan, warung kelontong dan warung makan. Hal tersebut karena adanya perpindahan penduduk dari luar daerah ke Desa Kubang untuk bekerja di industri jamu Banteng Gde.

\section{KESIMPULAN DAN SARAN}

\section{A. Kesimpulan}

Berdasarkan hasil penelitian, peneliti dapat menyiimpulkan penting untuk terus mengembangkan dan menggerakkan perekonomian di sekitar kita. Seperti berdirinya industri jamu Banteng Gde mampu berkontribusi dan memberikan perubahan bagi masyarakat Desa 
Kubang Kecamatan Sukamulya Kabupaten Tangerang. Meskipun tidak semua menjadi karyawan industri jamu tetapi dengan berdirinya industri jamu tersebut mampu membuka peluang usaha yang lain seperti membuka warung makan, warung kopi, warung gorengan sampai menyediakan/menyewakan tempat tinggal. Dengan demikian juga akan meningkatkan pendapatan masyarakat setempat. Secara langsung maupun tidak langsung berdirinya industri jamu Banteng Gde telah berkontribusi dalam penguatan ekonomi masyarakat Desa Kubang dan sekitarnya.

\section{B. Saran}

Berdasarkan hasil penelitian, yang bisa peneliti sarankan dalam upaya penguatan ekonomi masyarakat Desa Kubang dengan berdirinya industri jamu Banteng Gde dan disekitarnya, perlu dilakukan penguatan paradikma pada masyarakat akan khasiat tanaman herbal dan mengembalikan budaya menjaga kesehatan dengan mengkonsumsi tanaman herbal. Pencegahan lebih baik dari pengobatan. Kalau sebelumnya sebagian masyarakat berpenghasilan sebagai petani, artinya sangat memungkinkan dibudidayakan tanaman herbal sebagai bahan baku pembuatan jamu.

\section{DAFTAR PUSTAKA}

Ernie. 2013. Peraturan Menteri Kesehatan No. 246/MENKES/PER/V/1990 Tentang Izin Usaha Industri Obat Tradisional dan Pendaftaran Obat Tradisonal.
Fakultas

Kedokteran

Universitas Indonesia.

Istiqomah. 2017. Undang-Undang Nomor 20 Tahun 2008, tentang Usaha Mikro, Kecil dan Menengah. Pamulang: FKIP Unpam.

Istiqomah. $2017 . \quad$ Makna Keberhasilan Usaha Madu Di Pondok Pesanteren Darunnajah 2 Cipining. Skripsi tidak diterbitkan. Pamulang: FKIP Universitas Pamulang.

Krisyantono, 2009. Teknik Praktis Riset Komunikasi. Perdana Media Group. Jakarta

Moleong,L.J, 2011. Metode Penelitian Kualitatif Edisi Revisi. PT Remaja Rosdakarya. Bandung

Moleong,L.J, 2014. Metode Penelitian Kualitatif. PT Remaja Rosdakarya. Bandung.

Notoadmodjo, 2010. Metodologi Penelitian Kesehatan. Rineka Cipta. Yogyakarta

Profil Bisnis UMKM oleh LPPI dan BI tahun 2016

Rudjito, 2003. Peran Lembaga

Keuangan Mikro Dalam

Otonomi Daerah Guna

Menggerakkan Ekonomi

Rakyat.

Rudjito, 2003. Studi Kelayakan Bisnis. Rineka Cipta. Jakarta. Sugiyono. 2011. Metode Penelitian Kuantitatif Kualitatif dan R\& D. Bandung: Alfabeta.

Sulistiyono. 2015. Studi Kualitatif Deskriptif Perilaku Konsumen Rilisan Fisik Vynil Di Yogyakarta. Skripsi tidak 
diterbitkan. Yogyakarta : FE UNY.

Undang-Undang Nomor 20 tahun 2008 tentang Usaha Mikro Kecil dan Menengah

Widiyanti, Hera. 2005. Sejarah Perkembangan Industri Jamu Tradisional
Pengaruhnya Terhadap

Kehidupan Sosial Ekonomi Masyarakat Gentasari Kecamatan Kroya Kabupaten Cilacap Tahun 1990-200. Skripsi tidak diterbitkan. Semarang: FIS UNNES. 